\title{
Impactos Psicológicos do Uso de Celulares: Uma Pesquisa Exploratória com Jovens Brasileiros ${ }^{1}$
}

\author{
Ana Maria Nicolaci-da-Costa ${ }^{2}$ \\ Pontifícia Universidade Católica do Rio de Janeiro
}

\begin{abstract}
RESUMO - A literatura recente revela que, ao penetrarem em nossas vidas, inovações tecnológicas, como os computadores e a Internet, geraram importantes transformações psicológicas. Sabe-se muito pouco, no entanto, sobre os impactos psicológicos de outra nova tecnologia: a telefonia celular. Os resultados de uma pesquisa exploratória sobre o uso de celulares por jovens cariocas sugerem que a telefonia móvel também está produzindo alterações psicológicas. Indicam, ainda, que essas alterações são condizentes com a nova organização subjetiva - fluida e em constante transformação - descrita por vários analistas da era contemporânea. No caso desses jovens, as principais alterações identificadas dizem respeito: à dilatação da sua autonomia, liberdade e privacidade; ao incremento da intimidade em vários de seus relacionamentos; à emergência de novas formas de controle interpessoal; ao aumento de sua sensação de segurança e ao sentimento de nunca estarem sós.
\end{abstract}

Palavras-chave: inovações tecnológicas; celulares; jovens; impactos psicológicos.

\section{Psychological Impacts of the Use of Cell Phones: An Exploratory Study of Brazilian Youth}

\begin{abstract}
Recent studies show that, in the process of becoming part of our lives, technological innovations, such as computers and the Internet, have produced important psychological transformations. Little is known, however, about the psychological impacts of another new technology: mobile telecommunication. The results of an exploratory investigation into the use of cell phones by young inhabitants of Rio de Janeiro suggest that mobile telephony is also generating psychological changes. In addition, they indicate that such changes are consistent with the new subjective organization - fluid and ever-changing - described by several analysts of the present era. In the case of these youngsters, the most important changes detected are related to: their increased autonomy, freedom and privacy; the increased intimacy that characterizes many of their relationships; the emergence of new forms of interpersonal control; their increased sense of security and the feeling of never being alone.
\end{abstract}

Key words: technological innovations; cell phones; youngsters; psychological impacts.

Hoje, podemos dizer que a era moderna foi um período de relativa estabilidade entre dois momentos de muitas transformações. Como é de conhecimento geral, sua origem data de um período de profundas mudanças na estrutura e no funcionamento social, mudanças essas que foram geradas por uma revolução tecnológica, a Revolução Industrial (Castells, 2000; Nisbet, 1966). Já seus estágios mais recentes estão sendo marcados por outras inovações tecnológicas revolucionárias - as tecnologias da informação e telecomunicação - que estão novamente transformando as formas de vivermos em sociedade (Castells, 2000; Cebrián, 1999; Lévy, 1993).

Não são, no entanto, somente as formas de vivermos em sociedade que mudaram no início da era moderna e estão mudando agora. Se levarmos em consideração que, como argumentam Castells (2000) e Nicolaci-da-Costa (2002a),

1 Participaram da pesquisa relatada nesse artigo, as seguintes alunas do Departamento de Psicologia da PUC-Rio: Erika Falcão Ramalho, Maria Engel de Oliveira, Claudia Puntel Pereira dos Santos, Carolina de Sousa Aguiar Figueiredo, Roberta Beckowski, Daniella Muller de Campos Dantas Brasil. Agradeço ao CNPq e à FAPERJ pelas bolsas de produtividade e iniciação científica concedidas. Agradeço, também, a Daniela Romão-Dias e Carla Faria Leitão pela leitura cuidadosa das versões iniciais.

2 Endereço: Departamento de Psicologia, Rua Marquês de São Vicente, 225, Rio de Janeiro, RJ, Brasil 22543-900. E-mail: anicol@psi.puc-rio.br revoluções tecnológicas têm muito em comum no que diz respeito tanto às suas consequiências sociais quanto psicológicas, podemos fazer uma afirmação análoga à que fizemos acima, desta feita a respeito da organização subjetiva característica da modernidade. Neste caso, podemos dizer que a organização psíquica que conhecemos como a do indivíduo moderno também conheceu um período de relativa estabilidade entre dois períodos de muita transformação. O primeiro período de transformação levou à sua emergência. Já o segundo, não se pode prever ao certo que resultados terá na medida em que ainda está em curso.

A emergência do individualismo no século XIX, como uma conseqüência dos novos modos de produção industrial, dos processos de secularização das sociedades, das migrações das populações rurais para os recém-criados centros urbanoindustriais, do rompimento com as raízes comunitárias, do anonimato e isolamento urbanos, etc., já foi objeto de inúmeras análises, várias das quais foram recentemente discutidas por Nicolaci-da-Costa (2002a). Já a emergência de uma nova organização subjetiva, ainda sem nome de batismo consensual, mas cuja existência vem sendo identificada por inúmeros estudos (Bauman, 1997, 1999, 2001; Jameson, 1991; Leitão, 2003; Turkle, 1997; Romão-Dias, 2001; Sennett, 1998), requer atenção urgente. Isso porque, como veremos ao longo deste trabalho, a estabilidade moderna desapareceu e, em 
seu lugar, instalou-se um processo de constante mudança - e, conseqüentemente, de grande imprevisibilidade - com o qual a psicologia tem que aprender a lidar.

\section{As tecnologias da informação e telecomunicação}

As tecnologias da informação e telecomunicação - cujas manifestações de maior impacto social são a Internet e a telefonia celular - são convergentes. Para Castells (2000), um dos maiores analistas dos impactos revolucionários da Internet, quando falamos em tecnologias da informação forçosamente nos referimos a todo o conjunto convergente de tecnologias em microeletrônica, computação (software e hardware), telecomunicações, radiodifusão e optoeletrônica. ${ }^{3}$ Todas elas se complementam para gerar aquele que ele descreve como o espaço característico dos dias de hoje, o espaço dos fluxos.

Preocupado que está em analisar a nova organização social de nossos dias, a da sociedade em rede, Castells (2000) afirma que há

(...) uma nova forma espacial característica das práticas sociais que dominam e moldam a sociedade em rede: o espaço dos fluxos. O espaço dos fluxos é a organização material das práticas sociais de tempo compartilhado que funcionam por meio de fluxos (Castells, pp. 436-437, ênfase do autor.)

De modo mais simples, para Castells, a nova sociedade em rede tem como característica espacial específica o espaço dos fluxos, pelo qual flui e pode ser compartilhado em tempo real tudo aquilo que é imaterial. Esse espaço, por sua vez, é gerado por redes de computadores, fibras óticas, cabos, satélites e telefones celulares.

Embora ninguém possa discordar do fato de que essas tecnologias são convergentes e, ao se complementarem, geram espaços de vida alternativos aos convencionais, a literatura recente mostra que há algumas diferenças importantes no que se refere aos impactos sociais e psicológicos que a Internet e os celulares vêm causando.

Não parece haver mais dúvidas a respeito dos impactos sociais revolucionários da Internet. São vários os estudos (Castells, 2000; Cebrián, 1999; Lévy, 1993) que mostram que ela penetrou de tal modo os interstícios das sociedades contemporâneas e se tornou uma plataforma tão importante para o desempenho das mais variadas atividades (econômicas, políticas, educacionais, etc.) que muitos de seus analistas se preocupam com o fato de que amplos setores da população mundial a ela ainda não têm acesso (Bauman, 1999).

Como mostra uma revisão da literatura realizada por Leitão e Nicolaci-da-Costa (2000), os impactos psicológicos da Internet também vêm sendo objeto de estudo por vários pesquisadores. Estes afirmam que, diretamente (ou seja, a partir do uso direto que dela é feito) ou indiretamente (ou seja, a partir dos efeitos gerados pelas mudanças sociais que causou), a Internet vem gerando a emergência de uma nova organização subjetiva menos centrada, mais superficial, mais ágil, menos

3 Castells também inclui, nos domínios da tecnologia da informação, a engenharia genética e seu crescente conjunto de desenvolvimentos e aplicações. Esta inclusão foge, no entanto, aos objetivos desse trabalho. presa a projetos de longo prazo, etc. (Bauman, 1997, 1999, 2001; Jameson, 1991; Sennett, 1998; Turkle, 1997).

A intensidade com a qual tanto os efeitos sociais quanto os psicológicos da Internet vêm sendo estudados não encontra paralelo, contudo, no que diz respeito às investigações dos efeitos gerados pela telefonia celular.

Apesar da velocidade com que a telefonia celular vem se tornando presente nos mais variados recantos do planeta, Katz e Aakhus (2002) assinalam que é surpreendente constatar o relativo vazio de pesquisas acadêmicas sobre a mesma nas ciências sociais e humanas. De fato, até o ano de 2002, no qual estes autores lançaram uma coletânea que reúne artigos de várias procedências culturais, muito pouco havia sido publicado sobre os impactos que os celulares vinham tendo sobre os seus usuários.

Talvez uma das razões para isso resida no fato de que o cenário das pesquisas sobre celulares era, e ainda é, bastante diferente daquele - tradicional - no qual há uma grande concentração de estudos do universo anglo-saxão. Essa diferença de cenários, por sua vez, parece ter tido origem no fato de que, ao menos no início, a telefonia celular teve seu principal desenvolvimento e sua maior penetração nos países escandinavos (principalmente na Finlândia) e em alguns países asiáticos (Coréia do Sul, Singapura, Taiwan e Japão). Segundo Ling (2004), isso aconteceu por vários motivos, entre os quais estão as necessidades específicas da vida nesses países, os custos mais baixos de aparelhos e serviços neles praticados e a pouca resistência de seus habitantes ao uso celulares (ainda de acordo com Ling, os norte-americanos, por exemplo, são mais resistentes do que os finlandeses e noruegueses). Todo esse conjunto de fatores fez com que a literatura sobre os impactos sociais da telefonia celular fosse, até 2002, quase exclusivamente composta por iniciativas da parte de pesquisadores escandinavos, como Kopomoaa (2000), Mäenpäa (2001) e Roos (2001) e americanos residentes na Escandinávia, como Ling (2000). Esporadicamente, essas iniciativas eram complementadas por estudos encomendados por grandes empresas de telefonia celular como aquele levado a cabo por Plant (2001) a pedido da Motorola.

É, na realidade, a partir de 2003, que começam a ser publicados os estudos de Ito e seus colaboradores (Ito, 2003; Ito \& Daisuke, 2003) sobre o uso dos celulares no Japão, e as análises mais abrangentes levadas a cabo por investigadores norte-americanos, cujos pontos de partida também foram a realidade escandinava (Ling, 2004) ou japonesa (Rheingold, 2003). O ano de 2003 também presencia a divulgação dos resultados de um estudo minucioso do uso de celulares na Inglaterra (Roberts, Crabtree \& Nathan, 2003).

Muitas dessas investigações, a exemplo daquelas compiladas por Katz e Aakhus (2002), revelam que, apesar de os celulares virem tendo grande penetração em muitos países do mundo, as diferenças culturais nos seus padrões de adoção e na construção de regras de uso são muito grandes. Mesmo assim, na visão desses cientistas sociais, a telefonia celular já está gerando uma revolução.

Além da recorrente constatação de que os jovens (notadamente os adolescentes) estão sempre entre seus principais usuários, alguns indicadores comportamentais de mudanças micro-sociais - novos comportamentos e opiniões em relação 
a aspectos básicos do funcionamento social - estão presentes em praticamente todos os estudos acima citados.

O primeiro é a adoção dos celulares para a segurança de seus portadores, como no caso das chamadas de emergência principalmente em lugares ermos; sua contrapartida é o risco de acidentes que o celular pode acarretar quando o usuário está dirigindo. O segundo grande indicador está diretamente relacionado a um tema bastante caro ao pensamento sociológico, o da discussão do público e privado, principalmente na sua versão de privatização ou de disrupção dos espaços públicos em consequiência do uso de celulares na rua, nos meios de transporte, nas salas de espera de aeroportos, estações rodoviárias e ferroviárias, nos restaurantes, etc. $\mathrm{O}$ terceiro é a nova e flexível forma de coordenação de atividades, afazeres domésticos e programação social à distância que dispensa os horários e lugares previamente marcados; um uso radical desta nova forma de flexibilização, descrito por Rheingold (2003), é aquele empregado na orquestração de protestos políticos que podem congregar milhões de pessoas. Já o quarto é a versão contemporânea do surgimento de novas possibilidades de controle interpessoal (como aquela exercida por pais sobre filhos via celulares), que são a contrapartida das também novas possibilidades de autonomia individual na medida em que não há mais a necessidade de se estar em algum lugar previamente determinado para que se possa ser contatado.

No que diz respeito aos impactos psicológicos, entretanto, muito pouco pode ser encontrado na literatura. Dentro da psicologia e áreas afins, agora no cenário tradicional das publicações predominantemente em inglês, há estudos principalmente na área de riscos, como o do uso do celular ao dirigir um carro (Strayer \& Johnston, 2001; Wilson, Fang, Wiggins \& Cooper, 2003), e na área dos possíveis efeitos nocivos da radiação sobre o cérebro humano (Marino, Nilsen \& Frilot, 2003).

A despeito do fato de que as diferenças culturais impedem que seus achados possam ser generalizados para o contexto brasileiro, os estudos acima citados oferecem algumas indicações dos caminhos que uma investigação exploratória dos impactos psicológicos dos celulares sobre usuários brasileiros deve seguir. Minimamente, indicam que as populações jovens dos grandes centros urbanos podem ser um bom ponto de partida para uma investigação dos impactos psicológicos dos celulares no Brasil. Indicam, também, que é importante observar a penetração dos celulares na dinâmica familiar, o que se torna plenamente viável em estudos que tenham como participantes jovens que vivem com seus pais.

Com base nessas indicações, foi realizada uma pesquisa exploratória que tinha como principal finalidade a identificação e análise dos impactos psicológicos que os celulares vêm tendo exclusivamente sobre jovens de um grande centro urbano brasileiro, a cidade do Rio de Janeiro.

\section{Metodologia}

\section{Sujeitos}

Tendo em vista o caráter exploratório da pesquisa e a profundidade que se almejava alcançar, foi necessário que o estudo se concentrasse em torno de um pequeno grupo de jovens usuários. Para seu recrutamento foram estabelecidos alguns critérios: (a) Os sujeitos deveriam ser jovens entre 18 e 25 anos. (b) Para que fosse possível apreender os impactos do uso da nova tecnologia, deveriam ter bastante experiência nesse uso. Por isso, deveriam ter celular próprio há no mínimo um ano. (c) Para evitar que diferenças de poder aquisitivo interferissem no acesso a recursos disponíveis somente em celulares mais sofisticados - como toques diferenciados, $v i$ bracall, silencioso, etc. - e na própria frequiência de uso dos celulares, os sujeitos deveriam pertencer às camadas médias e altas da cidade do Rio de Janeiro. (d) Para que pudessem fornecer dados sobre possíveis alterações na organização e administração familiar, deveriam morar com outras pessoas (pais, avós, etc.). Não foram feitas quaisquer restrições a sexo ou profissão. Estes dados foram, no entanto, coletados.

Com base nesses critérios, foram recrutados vinte sujeitos - 14 mulheres e 6 homens - a partir de indicações de usuários conhecidos dos pesquisadores. À exceção de uma advogada de 23 anos e de um auxiliar de escritório de 22 , todos eram estudantes de $2^{\circ}$ ou $3^{\circ}$ grau. Todos moravam com um ou mais membros de sua família. Suas idades variavam entre 18 e 25 anos (a média era de 21 anos) e seu tempo de uso de celulares entre 2 e 9 anos (a média era de 4 anos). A todos foram atribuídos nomes fictícios para a preservação de seu anonimato.

\section{Coleta de dados}

Os dados foram coletados por meio de vinte entrevistas individuais de cerca de uma hora de duração. De modo que fossem informais e descontraídas, todas as entrevistas foram realizadas em locais escolhidos pelos próprios sujeitos. Tal procedimento foi adotado porque, para atingir a profundidade desejada, é fundamental que os entrevistados se sintam à vontade para revelar ao pesquisador suas opiniões, pensamentos e sentimentos (Labov, 1972; Nicolaci-da-Costa, 1989).

A entrevista era levada a cabo tendo como base um roteiro - construído de acordo com as diretrizes propostas por Nicolaci-da-Costa (1989) - que contemplava os objetivos exploratórios da pesquisa. Como pode ser observado abaixo, o roteiro era composto de 30 itens principais a partir dos quais eram geradas as perguntas. Estas eram formuladas durante a própria entrevista para evitar que fossem lidas e, em consequiência, soassem artificiais (a entrevista deveria se assemelhar tanto quanto possível a um bate-papo informal). Esses 30 itens/perguntas poderiam ser desmembrados em outros, para maior aprofundamento. A maior parte desse roteiro era composta de itens/perguntas abertos (que permitem qualquer tipo de resposta). Quando necessários, eram incluídos itens/perguntas fechados (cujas respostas são sim e não), sempre seguidos de perguntas de aprofundamento, como: "por quê?"; "como?”; “onde?”, “dá para explicar melhor?". Os itens/perguntas do roteiro eram agrupados em blocos temáticos, que são apresentados, na íntegra, a seguir.

Diferenças entre o telefone fixo e o celular: Quais as principais diferenças entre o telefone fixo e o celular, quando usa um ou o outro (por quê), qual telefone dá primeiro (por quê), qual usa para conversas privadas (por quê), para qual os amigos ligam primeiro (por quê), para qual o entrevistado liga primeiro quando quer falar com os amigos (por quê), para 
qual o entrevistado liga primeiro quando não tem intimidade com o interlocutor (por quê), para qual liga primeiro quando tem intimidade (por quê).

Uso do celular:

a) Rotina de uso: se o entrevistado tem o celular sempre por perto (onde?); qual a rotina de uso (investigar se recebe mais chamadas ou se faz mais chamadas); como se sente com a possibilidade de ser encontrado a qualquer hora; quanto tempo deixa o celular ligado por dia (quando deixa desligado; quando deixa na campainha, no vibracall ou no silencioso); se atende à qualquer hora (em caso negativo, quando não atende; quais os critérios que usa para atender ou não); se olha no visor antes de atender (em caso positivo, o que faz após olhar o visor); se há pessoas que o entrevistado sempre atende (em caso positivo, quem são e por que sempre atende); se há alguém que o entrevistado nunca atende (em caso positivo, quem e por quê); se usa toque diferenciado (em caso positivo, para quem, por quê, quantos, etc.).

b) Caso o entrevistado deixasse o celular ligado 24 horas por dia: o que acha de receber ligações de madrugada quando está em casa (quem liga a essa hora, por quê); o que acha de receber ligações de madrugada quando está na rua (quem liga, por quê).

c) Outros usos: o que o entrevistado faz quando alguém liga a cobrar (quem liga a cobrar, por quê, como o entrevistado se sente); como o entrevistado usa a agenda do celular (qual a capacidade desta, quantos números estão armazenados, de quem, se esses números estão armazenados somente no celular e, em caso negativo, onde mais).

Como o entrevistado se relaciona com o seu celular: se empresta o celular (em caso positivo, como e por quê); como se sentiria se visse alguém atendendo seu celular sem permissão (por quê); como se sentiria se visse alguém mexendo no seu celular sem permissão (por quê); se já perdeu o celular ou o teve roubado (em caso positivo, como se sentiu; em caso negativo, como acha que se sentiria); se o entrevistado vê diferença no seu uso do celular ao longo do tempo (em caso positivo, qual, por quê); qual o papel que o celular tem na sua vida.

Privacidade e intimidade: o que é privacidade; como fica a privacidade com o uso do celular; o que é intimidade; como fica a intimidade com o uso do celular.

\section{Análise dos dados}

Todas as entrevistas foram integralmente transcritas e, em seguida, submetidas às técnicas de análise qualitativa de discurso, desenvolvidas por Nicolaci-da-Costa $(1989,1994)$ e utilizadas em várias de suas pesquisas, como, por exemplo, em Nicolaci-da-Costa (1998, 2002b). Essa análise é realizada em duas grandes etapas. Na primeira, são feitas comparações inter-sujeitos. Para tanto, são reunidas todas as respostas de todos os sujeitos a cada um dos itens/perguntas, procedimento que dá ao pesquisador uma visão panorâmica dos depoimentos gerados por cada um desses itens/perguntas. As respostas recorrentes nos discursos analisados nesta etapa já indicam os primeiros resultados - ou seja, as tendências centrais das respostas dadas pelo grupo como um todo -, embora estes ainda necessitem de aprofundamento. Já na segunda etapa
- a da análise intra-sujeitos -, as respostas de cada um dos sujeitos são analisadas como um único conjunto dentro do qual procura-se detectar possíveis conflitos de opiniões, inconsistências entre respostas, sentimentos contraditórios, etc. Tendo por base o insight ganho nesta segunda etapa, retorna-se à primeira e efetua-se uma re-análise das respostas dadas por todos os sujeitos a cada uma das perguntas. Estas idas e vindas (que podem ser repetidas quantas vezes forem necessárias) possibilitam o conhecimento aprofundado do material coletado e permitem detectar, além de vários nãoditos (pois, muitas vezes, o que não é verbalizado em uma resposta é claramente verbalizado em outra), os pormenores de sentimentos, conflitos internos e porquês que a pesquisa se propõe a identificar.

\section{Resultados}

Como será mostrado a seguir, muitos dos indicadores de mudança micro-social que surgiram recorrentemente nas pesquisas relatadas no início deste artigo (novas concepções de segurança, novas concepções de público e privado, novas formas flexíveis de coordenação de atividades e programação, novas formas de controle interpessoal), também emergiram dos nossos resultados. $\mathrm{Na}$ realidade, esses indicadores de mudança micro-social, se adequadamente interpretados, podem ser muito úteis como indicadores de mudanças psicológicas, pois estas são muitas vezes decorrentes das primeiras. Exploremos, agora, esses indicadores e tentemos compreender aquilo que eles podem nos revelar a respeito das mudanças internas geradas em nossos jovens entrevistados pelo uso dos celulares.

Um bom indicador da importância que os celulares assumiram nas vidas dos entrevistados é o fato de que todos têm seus celulares sempre por perto (geralmente na bolsa, no caso das mulheres, ou no bolso da calça ou bermuda, no caso dos homens). Flávia Dantas explica em detalhes onde está seu celular em diferentes situações de rotina:

Eu durmo com o celular do lado da cama, geralmente meu namorado me liga de madrugada, tipo de noite e tal, ou alguém pode me ligar de madrugada... Eu acordo, pego o celular ponho ele dentro da bolsa, venho para faculdade de ônibus ou de carona com a bolsa. Então, eu pego o celular. Durante as aulas eu ponho ele no meu colo e, no estágio, eu deixo ele em cima de uma mesa, (...) mas tem que estar sempre visível, sempre perto.

Bruno Batista ainda vai mais longe. Admite carregar seu celular até para o banheiro: "Ando com ele pra cima e pra baixo, onde eu tiver, eu tô com o celular, no banheiro eu tô com celular. Pode ligar que vai me achar e eu não desligo pra dormir".

A necessidade de estarem sempre disponíveis faz com que, tal como acontece com Flávia e Bruno, a grande maioria dos entrevistados nunca desligue seus celulares (os poucos que o fazem, desligam somente para dormir). Os depoimentos de Juliana Araújo e Bianca Falcão são típicos. Juliana mantém seu celular ligado: “... sempre, até de madrugada. É raro, é raríssimo deixar ele desligado... Hoje em dia, eu vou ser sincera ..., acho que nem em prova eu deixo mais 
desligado, eu boto pra vibrar. A dependência é tão grande..." Bianca faz o mesmo, deixa seu celular ligado o tempo todo. Não desliga: “... nem no curso, nem no cinema, sempre deixo pra vibrar. Você só vai encontrar meu celular desligado se tiver acabado a bateria e eu tiver na rua."

E não é à toa que os celulares estão sempre ligados e por perto. Eles só não atendem as chamadas quando realmente não podem fazê-lo (como, por exemplo, durante provas) e, nessas ocasiões, querem saber quem chamou para retornar mais tarde. São curiosos e não querem perder nada. Luís Mello, que é outro que não pode se separar do celular nem para ir ao banheiro, dá as suas razões para se comportar assim. Ele tem o celular sempre por perto:

... pra não perder nenhuma ligação mesmo, mesmo que eu não possa atender eu quero saber quem me ligou. Tipo agora, eu poderia ter desligado o celular pra fazer a prova, mas eu fale $i$ não, vou deixar ele no silencioso, vai tocar dez vezes, não vou atender, mas eu vou saber quem me ligou. E tá sempre por perto, às vezes eu tô nos lugares mais bizarros... Eu levo pro banheiro, entendeu.

Podendo atender, eles olham o visor e atendem independentemente de identificarem ou não quem está chamando. Priscilla Costa dá um bom exemplo desse tipo de comportamento: "Atendo tudo. Atendo porque de repente é alguém que realmente precisa falar comigo mas eu não gravei o número nem nada ..."

Se sempre atendem, por que olham o visor antes de atender? Vanessa Sá e João Martins explicam. É para saber como atender, pois, no celular, o atendimento é personalizado, o que torna a proximidade psicológica maior a despeito da distância. Vanessa diz que olha o visor:

... porque eu quero saber quem tá me ligando e ... não sei, é mais fácil de atender também, você vê que ... vê por exemplo, é uma amiga minha, já falo "Oi, fulaninha!" Diferente, de ligação, tipo, em casa... É, em casa é aquele "alô!”...

E João complementa. Ele faz isso "para saber quem é, para falar: Oi fulano!!! Fazer uma piada e tal..”. Para que isso possa acontecer, nomes e telefones têm que estar armazenados na agenda dos celulares. Na maior parte das vezes, os entrevistados usam a capacidade de suas agendas (que os fabricantes de celulares tornam cada vez maior) ao limite. Carla Nóbrega, por exemplo, afirma, com um certo orgulho, que a sua agenda:

Tá lotada, não cabe mais nenhum. Acho que são cem. ${ }^{4}$ É, mas olha e eu acho que tem pouco sabe? Mas são as pessoas ou que eu ligo mais ou que me ligam mais, sabe? Óbvio, eu acho que dessas 99 , eu acho que uns $60 \%$ são pessoas que eu tenho muito contato outras eu tenho porque é aquela coisa assim... Você encontra alguém no meio da rua, nunca mais a gente se falou não sei o que, qual seu telefone e anota.

4 Em menos de um ano, essa capacidade foi quintuplicada na maioria dos aparelhos celulares.
Com tantos números armazenados, fica difícil não identificar quem está chamando e as formas de atender raramente são impessoais como no caso do telefone fixo sem identificador de chamadas.

Não são, porém, somente as formas de atender que são personalizadas. A difusão e a popularização dos celulares dão lugar a uma nova forma de personalização das chamadas: a do acesso direto e imediato à pessoa com quem se deseja falar. Os jovens entrevistados da pesquisa deixaram muito claro que não gostam de intermediários. Por isso, entre ligar para o telefone fixo ou para o celular de uma pessoa, geralmente optam pelo celular. (Se o custo fosse o mesmo, muito provavelmente sequer pensariam em fazer ligações para ou de telefones fixos.) Tomando os atalhos da área de trabalho do Windows como metáfora, pode-se dizer que ligar para o celular é o mesmo que usar uma forma de atalho para se ter acesso direto ao interlocutor desejado. Carla Nóbrega revela como usa o celular com esse tipo de finalidade:

A galera tá assim, geral, às vezes eu me pego fazendo isso também: eu vou ligar pra fulana, eu quero achar ela, vou ligar pro celular, porque eu sei que mesmo que ela esteja em casa, ela vai tá com o celular ligado no quarto. Eu acho que, às vezes, eu me pego fazendo isso também... Acho que ... vem a facilidade primeiro de encontrar a pessoa. E, segundo, tipo meio que ter certeza, certeza entre aspas, de que ela vai atender. Então se eu quero falar com ela, por exemplo, minha mãe. Às vezes eu quero falar e tá no trabalho, então no escritório dela é assim, a telefonista que passa pra secretária dela que passa pra ela. Saco! Quero falar com ela. Aí, eu prefiro, tipo, tentar o celular dela, aí eu já falo direto com ela.

Mateus Oliveira e a maior parte dos outros entrevistados também têm a mesma opinião. Mateus a coloca de forma compacta:

O celular você liga para a pessoa e acha, vai direto ao ponto, tem a certeza de que a pessoa vai atender, e o fixo, é... o fixo. Você liga para a pessoa e atende alguém da casa, tem que pedir pra chamar. Celular, a pessoa ligou é para mim.

Luís Mello tem um depoimento a respeito do uso de atalhos, que complementa esses dois primeiros. Afirma não gostar que ninguém atenda seu celular e explica por quê: "[Se] acontece de alguém atender seu telefone e a pessoa que liga reconhece que não é você, desliga. Porque sófala se for com você. É por isso que eu não gosto." Ou seja, quem chama desliga se, ao usar um atalho, quem atende é um intermediário.

Os atalhos são muito apreciados e usados pelos entrevistados também por outros motivos: lhes dão autonomia e preservam a privacidade. $\mathrm{O}$ uso de atalhos permite que liguem para os amigos (e deles recebam ligações) a qualquer hora do dia e da noite (porque somente os destinatários atenderão). Quando estão em casa, esse recurso protege, também, sua privacidade dos ouvidos curiosos de familiares. A respeito de telefonemas a qualquer hora, Priscilla Costa diz: "Se for muito tarde, assim, eu prefiro ligar pro celular. Eu sei que o celular deve tá no quarto da pessoa e só ela vai atender. Não tem problema de eu estar atrapalhando ninguém." Já Viviane Batista mostra como o celular protege sua privacidade. Ela 
revela que, quando conhece uma pessoa, dá sempre o número de seu celular primeiro.

Porque eu passo o dia fora de casa e tipo, celular é muito melhor, né? Porque, bem ou mal, se eu der o telefone fixo, ainda mais eu que passo muito tempo longe de casa, é minha mãe que vai atender, entendeu? Pô, às vezes eu conheço um cara, aí dá o telefone pro cara, entendeu, cada hora um ligando par minha casa, é chato.

Todos esses comportamentos - ter o celular sempre ligado e por perto, atender todas as chamadas, usar atalhos, etc. - geram um constante fluxo de ligações ao longo do dia e da noite, inclusive de madrugada. A sociabilidade desses jovens é intensa e fluida. Não há muito espaço para a solidão. O depoimento de Luiz Mello revela o que acontece durante o dia: "É geralmente assim, quando eu ligo geralmente eu falo rápido. É difícil eu ficar muito tempo. Geralmente, assim, é mais pra aviso mesmo: cheguei, tô saindo, tá aonde... É muito difícil eu ligar pra alguém pra bater papo." O mesmo acontece quando estão na night. Ainda de acordo com Luiz:

$100 \%$ das vezes que eu tô na rua e recebo ligação de madrugada é o pessoal que tá comigo na rua. Tipo, assim, às vezes saem três carros aí um se perde do outro "ah, onde você tá?", ou então marca comigo na porta do cinema meia noite, aí me ligam e falam "já cheguei”, entendeu. Ou então "olha só, a gente não gostou daqui, não, porque aqui tá vazio. A gente tá indo lá pro bar não sei das quantas.

O uso que Luiz faz de seu celular na night é típico. Todos os outros entrevistados revelam fazer uso semelhante. ${ }^{5}$ Para João Martins, o uso se intensifica justamente quando ele e os amigos vão se encontrar para fazer programas:

De noite [o número de ligações] aumenta pra caramba. É a hora que eu mais falo pra saber onde as pessoas estão, onde tá bom... Durante o final de semana é o pico!!! É quando eu mais preciso dele, saber o que está acontecendo, o que tá pegando, muito importante...

Na night, eles só não gostam de receber telefonemas dos pais. Viviane Batista, por exemplo, acha que a mãe a vigia demais. Para ela, o celular tem uma desvantagem:

... minha mãe me acha em todos os lugares, sabe, não tenho mais aquela desculpa de "ah, não tinha telefone"... É, eu não gosto muito disso, dessa marcação cerrada não, sabe. [Por quê?] Ah porque eu gosto muito de liberdade, assim, aí pô, às vezes ela me liga 4 h da manhã, ah tá ainda aí?... Ai que saco, sabe, nem atendo.

Claudia Pereira não chega a não atender, mas também se sente muito incomodada com os telefonemas do pai. Segundo ela, ele liga: “... porque quer ficar me controlando, né? Eu acho que todo pai que dá celular pro filho, no fundo, no fundo, quer ficar é controlando o filho e não porque é bonzinho."

5 Sociabilidade análoga, entre adolescentes cariocas, é analisada por Almeida e Tracy (2003).
Não é, no entanto, somente quando estão na rua que muitos desses jovens fazem uso de seus celulares. Como já foi dito, a maioria deixa-os ligados ao longo da noite. E isso acontece porque, mesmo de madrugada, têm autonomia para receber telefonemas, pois os telefones estão por perto em seus quartos. Alguns entrevistados afirmam não se importar de receber ligações dos amigos de madrugada. Estes ligam por diferentes razões, entre as quais estão brigas com namorados, crises de depressão ou solidão e até mesmo simples fofocas. Viviane Batista deixa seu celular ligado ao longo da noite porque:

Tem amiga minha que me liga durante a madrugada, deprê, ou então para contar alguma coisa. Geralmente é amiga, assim, pra falar alguma coisa, ou pra reclamar da vida, ou então pra contar que saiu com um cara, não sei que, não sei que lá...

Flávia Dantas também não tem restrições quanto a receber ligações de madrugada quando está em casa. Diz: “Eu não tenho problema com isso, se as pessoas tão me ligando de madrugada é porque tão precisando falar comigo." [Normalmente isso acontece por quê?] Quando as amigas brigaram com o namorado, quando estão tristes, precisando conversar.

Todo esse acesso direto e imediato ao outro com quem se quer conversar ou desabafar, para quem se quer contar alguma fofoca ou perguntar alguma coisa - cuja contrapartida é dada pela receptividade desse outro - faz com que esses jovens partilhem uns com os outros diversos aspectos de seu cotidiano. Falam, inclusive, que sentem uma necessidade de falar com o outro imediatamente quando aparece a vontade. Segundo Vanessa Sá, cujo depoimento encontra eco em vários outros:

É uma coisa mais recente isso... porque antigamente não existia celular e as pessoas ligavam pra outra, se tivesse ocupado fazer o que, né? Ligava depois. Mas aí, depois que apareceu o celular já tem essa... essa vontade de falar com a pessoa naquele segundo...

A comunicação entre esses jovens é tão freqüente que alguns chegam a ser da opinião de que os celulares aumentam a intimidade de certas relações. Esse é o caso de Carla Nóbrega, para quem o uso do celular facilita a construção da intimidade:

É, eu acho que às vezes facilita. Por exemplo, eu acho que esse negócio de namorado, por exemplo, ele ligar qualquer hora. Antigamente era só em casa, mãe atendia e às vezes ficava com vergonha. Acho que poder ligar, poder mandar mensagem de texto pode ajudar a ir criando a intimidade, pode aumentar.

Também é o caso de Luís Mello, que acha que o celular aproxima mais as pessoas: "É...acaba que [o celular] aproxima mais, né? Eu acho que acaba fazendo com que as pessoas fiquem mais íntimas.”

O intenso uso que fazem dos celulares para a manutenção de sua rede social e de sua programação tem uma outra importante conseqüência: quando ficam sem o celular (no caso deste quebrar, ser perdido ou roubado) os jovens entrevistados 
sentem que perderam o contato com o mundo. Alguns de seus depoimentos a esse respeito são bastante enfáticos. Juliana Araújo, por exemplo, afirma que o celular:

É o principal meio de comunicação [rindo]. Eu me sinto, assim, hoje em dia, segura, e se eu sair de casa sem o celular eu fico, assim, se eu tiver sem o celular e precisar falar com alguém “como é que eu vou fazer?”. (...) A dependência é tão grande que você acha que você tem que estar com ele todo momento.

Viviane Batista é ainda mais dramática. Diz que se ficasse sem o celular: "Ia faltar alguma coisa, imagina vir para a faculdade e ficar sem o celular. Como eu ia falar com alguém? Não dá. Ia ser horrível."

O depoimento de Paula Mendes, no entanto, é o mais radical:

Não consigo sair de casa, eu não fico sem celular, parece que eu tô sem calcinha, sem cabeça. Se eu sair sem celular, eu dou um jeito, volto. Ficar sem bateria é um desespero porque, ao mesmo tempo que eu quero falar com as pessoas, as pessoas querem falar comigo. Se não conseguirem, ficam nervosas. “Onde é que você tá?" Então, é imprescindivel (...) Vicia, faz. parte do corpo quase.

Esses depoimentos nos fornecem uma importante pista para compreender o papel que o celular desempenha na vida dos entrevistados. Se sua falta os deixa desorientados, inseguros e sós, o fato de terem-no por perto gera uma sensação de segurança e de estarem acompanhados. De fato, a questão da segurança aparece explicitamente em todas as entrevistas. Seguem-se alguns exemplos.

Flávia Dantas acha muito bom ter um celular porque:

Meus pais já se preocuparam muito com a minha demora, com o trânsito, violência. É para mim uma segurança, é de eu estar de repente num carro e acontecer alguma coisa e eu ter a quem chamar.. É uma segurança.

Já João Martins, embora não goste muito de carregar seu celular para todos os lugares, afirma não dispensar seu uso por razões análogas:... não gosto muito de celular, de carregar, é importante, mas é meio chato. [Por que é importante?] Para a minha segurança... é sempre importante ter um celular na mão para o que der e vier.

A sensação de estarem sempre acompanhados, proporcionada pelos celulares, também aparece em todas as entrevistas. Duas entrevistadas chegam, inclusive, a admitir explicitamente que vêem seus celulares como companheiros. Carla Nóbrega, por exemplo, diz:

... pensando nele [celular] hoje em dia na minha vida ... eu acho que eu vejo talvez até como, inventando uma palavra, até como companheiro. [Risos] É engraçado, tipo, tô sem ter o que fazer, vou aproveitar pra fazer aquelas ligações, ou vou jogar aquele joguinho que tem no celular, ou enfim, vou mandar uma mensagem de texto.

E Paula Mendes parece completar: "É uma relação, quase um melhor amigo mesmo."

\section{Discussão}

\section{Algumas conseqüências psicológicas do uso de celulares entre os jovens entrevistados}

Como diz Castells (2000), o conjunto das tecnologias da informação e telecomunicação gera um novo tipo de organização social, o da sociedade em rede. Em um mundo como esse, em que tudo potencialmente se conecta a tudo e todos a todos, o uso de indicadores micro-sociais deve ser complementado pelas visões macro-sociais fornecidas por especialistas. Se deixarmos de lado essa perspectiva macro e procurarmos analisar os impactos psicológicos dos celulares fora do contexto das consequiências sociais e psicológicas que vêm sendo geradas por outras tecnologias, correremos o risco de prejudicar nossa capacidade de interpretar o complexo emaranhado das transformações que estamos sofrendo por vivermos no mundo em que vivemos e usarmos as tecnologias que usamos. Ou seja, correremos o risco de realizar uma análise míope e descontextualizada.

Segue-se que, para fazer sentido do uso dos celulares no mundo de hoje, precisamos recorrer às análises da realidade dos nossos dias, empreendidas por intelectuais que tentam captar as características distintivas tanto do tecido social contemporâneo quanto das transformações subjetivas que este vem gerando. E aqui talvez seja útil lembrar que, embora muitas vezes isso não seja por eles tornado explícito, esses intelectuais analisam uma realidade que tem sua infra-estrutura dada pelo conjunto das modernas tecnologias da informação e telecomunicação (e também as de transporte). Passemos à discussão de algumas de suas percepções.

Bauman (1997, 1999, 2001) e Deleuze e Guattari (1995), por exemplo, apontam o nomadismo e a fluidez - cujas manifestações mais visíveis são a constante circulação de pessoas, de bens e do capital - como algumas das principais características da dinâmica social contemporânea. Bauman (2001) acrescenta a essas duas características uma outra: a da extraterritorialidade de alguns ingredientes da vida em sociedade, ingredientes esses que - a exemplo do capital - passam a prescindir de vínculos territoriais fixos, na medida em que podem migrar de um local para outro, em questão de instantes, tendo como suporte as modernas redes de telecomunicação.

É interessante observar que esses mesmos atributos podem ser transpostos do nível macro-social, em que se situam as análises acima mencionadas, para o nível microsocial e individual, no qual se localiza a pesquisa que vimos relatando. Em outras palavras, a despeito da mudança de nível, nossos resultados revelam que o nomadismo, a fluidez e a extraterritorialidade caracterizam o cotidiano dos jovens participantes da pesquisa.

De fato, esse cotidiano torna visível um novo tipo de nomadismo urbano que revela ter características bastante diferentes daquelas dos nomadismos tradicionais. Esse novo nomadismo tem na telefonia celular sua condição de possibilidade. Isso porque, como já foi visto, os jovens que participaram da pesquisa não vagam solitariamente ou têm seus horizontes sociais limitados aos membros de um único grupo que se movimenta em conjunto. Muito pelo contrário, como nossos resultados deixam claro, o escopo de sua rede 
de sociabilidade, e provavelmente da de muitos outros novos nômades, é potencialmente ilimitado. Qualquer que seja seu itinerário, eles carregam consigo não somente sua ampla rede social - as vias de acesso à qual já estão armazenadas em seus celulares - como também a possibilidade de nela incorporar novos membros encontrados pelo caminho.

As alterações que estão sendo introduzidas pelos celulares na vida dos jovens entrevistados não dizem respeito, no entanto, exclusivamente à sociabilidade móvel, imediata e constante que viabilizam. No nível individual, outras alterações - desta feita, internas - podem ser detectadas a partir dos resultados da presente pesquisa. Pelo fato de estas mudanças serem muito recentes e/ ou ainda estarem em curso, contudo, sua discussão encontra seu principal apoio nos inúmeros registros de que novas tecnologias têm o poder de gerar importantes transformações subjetivas (Leitão \& Nicolaci-da-Costa, 2000; Nicolaci-da-Costa, 2002a).

A primeira dessas alterações pode ser observada no que diz respeito à grande autonomia e liberdade de ação das quais os jovens participantes da pesquisa desfrutam. $\mathrm{Na}$ rua, contanto que estejam "no celular", eles praticamente vão onde querem à hora que querem, pois, em princípio, seus pais podem achá-los em qualquer lugar e a qualquer hora (vimos, no entanto, que frequientemente consideram os telefonemas destes como uma invasão, ressentindo-se do controle à distância, por vezes bastante freqüente $)^{6}$.

Não é, entretanto, somente quando estão fora de casa que esses jovens gozam de uma autonomia e uma liberdade inexistentes até poucas décadas. Como já mencionado, os celulares tornaram possível que, também dentro de casa, eles tenham uma autonomia surpreendente por padrões tradicionais. Por meio do acesso direto ao interlocutor, facultado pelo uso daquilo que chamamos de atalhos, adquiriram, por exemplo, a liberdade de fazer ou receber telefonemas, não importa a hora, sem que isso seja do conhecimento dos outros membros da família. Essa liberdade, por sua vez, tem como consequiência, direta e imediata, a dilatação substancial do que vêem como sua área de privacidade. Esta, além de móvel, se torna tão ampla que, mesmo de madrugada na casa de seus pais, eles podem se permitir oferecer solidariedade aos amigos que precisam de alguém para dividir suas mágoas ou para partilhar suas alegrias.

Os contatos imediatos propiciados pelo uso de atalhos põem por terra diversas barreiras - físicas e simbólicas - e tornam antigas formas de controle obsoletas. Fazem desaparecer os intermediários, as horas e lugares impróprios, ou, ainda, as restrições familiares a um ou outro amigo ou conhecido. Também põem fim à possibilidade de os pais terem conhecimento daquilo que os entrevistados desejam manter distante de seus ouvidos. O telefone da casa é o telefone da família e, se possível, é raramente utilizado, quer pelos entrevistados quer por aqueles que os chamam. Os entrevistados, seus amigos e namorados procuram ao máximo manter sua privacidade longe da vigilância dos membros de seus círculos familiares.

6 O controle à distância dos filhos provavelmente se intensificará quando forem difundidas as tecnologias de rastreamento já existentes. Este é um aspecto a ser investigado tão logo essas tecnologias se tornem populares.
Esta privacidade, por seu turno, faz com que as chamadas feitas entre amigos e namorados sejam muito freqüentes, tanto durante o dia quanto durante a noite. Dado que a telefonia celular tornou o contato imediato com o interlocutor possível e fácil, eles passaram a sentir necessidade de dividir com os amigos e namorados, de forma imediata, tudo o que de bom ou mau lhes acontece. Como conseqüência, alguns já demonstram ter consciência de que essa partilha está gerando um incremento na intimidade de vários relacionamentos.

Ainda outro importante efeito que o uso de celulares vem tendo sobre a organização subjetiva dos jovens entrevistados está relacionado à sensação de segurança (que independe do grau de segurança real) que a possibilidade de recorrer a alguém lhes proporciona (quer seja por conta de um pneu furado, quer seja por conta de uma briga com o namorado). Sua liberdade de ação e sua autonomia fazem com que se exponham mais ao mundo e aos outros. De posse de seus celulares, contudo, nunca se sentem sozinhos. Sabem que podem contar com uma extensa rede de solidariedade para os mais diversos tipos de emergência (como, por exemplo, a solidariedade ao longo da madrugada relatada anteriormente).

Diante da liberdade, da autonomia e da privacidade precoces (por padrões tradicionais), que a telefonia celular lhes outorgou, bem como da intensa, fluida, instantânea e espontânea sociabilidade que viabilizou, não é de espantar esses jovens vejam seus celulares como indispensáveis para as suas vidas (não custa lembrar que alguns chegam a falar deles como companheiros ou amigos). Por isso se desesperam quando, por algum acidente, não estão de posse do seu. Admitem depender dos celulares para subsidiar seu nomadismo e manter contato com o mundo fluido em que vivem. Sem eles, perdem o acesso imediato à sua rede social. Na ausência desse acesso, sentem-se excluídos do convívio de seus amigos, parentes, namorados, etc. e enfrentam uma nova forma de solidão, não menos dolorosa do que as tradicionais: a solidão do sedentário em um mundo de nômades em constante movimento.

\section{Conclusão}

Tanto a literatura sobre os impactos subjetivos da Internet como os resultados que acabam de ser discutidos mostram que os constantes desenvolvimentos de novas tecnologias de informação e telecomunicação vêm produzindo transformações internas (em áreas centrais como as da autonomia, liberdade individual, privacidade, intimidade, etc.) e emprestando novos significados a antigos sentimentos (como no caso da nova solidão discutida acima). Isso significa dizer que a relativa estabilidade que caracterizava as formas de ser ao longo do século XX já deixou de existir, ou está em vias de fazê-lo. Em seu lugar, a fluidez e o movimento emergem como talvez suas únicas características constantes.

A fluidez e o movimento como marcas registradas da subjetividade contemporânea não passam despercebidas a olhares atentos, mesmo quando esses olhares não as vinculam explicitamente aos desenvolvimentos tecnológicos de nossos dias (pois os pressupõem). Este é o caso de Bauman (1997) e Deleuze e Guattari (1995).

Bauman, por exemplo, afirma que: "o eixo da estratégia de vida moderna não é fazer a identidade deter-se - mas 
evitar que se fixe” (Bauman, 1997, p.114). Já Deleuze e Guattari propõem que pensemos a subjetividade a partir da noção de rizoma:

Um rizoma não começa nem conclui, ele se encontra sempre no meio, entre as coisas, inter-ser, intermezzo. A árvore é a filiação, mas o rizoma é aliança, unicamente aliança. A árvore impõe $o$ verbo 'ser', mas o rizoma tem como tecido a conjunção 'e... e... e...'. Há nesta conjunção força suficiente para desenraizar o verbo ser. (Deleuze \& Guattari, 1995, p. 37)

Para Deleuze e Guattari, a fluida subjetividade contemporânea, tal como o rio na conhecida letra da música Old man river, de autoria de Jerome Kern e Oscar Hammerstein, está sempre em movimento e em transformação. "He don't plant tatos/ Don't plant cotton/ Them that plants them is soon forgotten/But old man river he just keeps rollin along" (citada por Deleuze \& Guattari, 1995, p. 37). ${ }^{7}$

Para concluir, pode-se afirmar que, se a transformação subjetiva passou a ser constante, cabe à psicologia acompanhá-la de perto, o que torna particularmente relevante e forçosamente incompleta - pois novos desenvolvimentos tecnológicos poderão levar a novas transformações subjetivas - a discussão travada neste artigo.

\section{Referências}

Almeida, M. I. M. \& Tracy, K. M. A. (2003). Noites nômades: Espaço e subjetividade nas culturas contemporâneas. Rio de Janeiro: Rocco.

Bauman, Z. (1997). O mal-estar da pós-modernidade. Rio de Janeiro: Jorge Zahar.

Bauman, Z. (1999). Globalização: As conseqüências humanas. Rio de Janeiro: Jorge Zahar.

Bauman, Z. (2001). Modernidade líquida. Rio de Janeiro: Jorge Zahar.

Castells, M. (2000). A sociedade em rede. São Paulo: Paz e Terra.

Cebrián, J. L. (1999). A rede: como nossas vidas serão transformadas pelos novos meios de comunicação. São Paulo: Summus Editorial.

Deleuze, G. \& Guattari, F. (1995). Mil platôs: Capitalismo e esquizofrenia, São Paulo: Editora 34.

Ito, M. (2003). A new set of social rules for a newly wireless society. Retirado em 11/12/2003, do http://www.ojrorg/japan/ wireless/1043770650.php

Ito, M. \& Daisuke, D. (2003). Mobile phones, Japanese youth and the re-placement of social contact. Retirado em 11/12/2003, do http://www.itofisher.com/PEOPLE/mito/mobileyouth.pdf

Jameson, F. (1991). Pós-modernismo: A lógica cultural do capitalismo tardio. São Paulo: Ática.

Katz, J. E. \& Aakhus, M. (Orgs.). (2002). Perpetual contact: Mobile communication, private talk, public performance. Cambridge: Cambridge University Press.

Kopomoaa, T. (2000). Speaking mobile: The city in your pocket. Helsinki: Gaudeamus.

7 Ele não planta batatas/ Não planta algodão/ Aqueles que os plantam são logo esquecidos/ Mas o velho homem rio simplesmente continua a correr.
Labov, W. (1972). The logic of nonstandard English. Em W. Labov, Language in the inner city (pp. 201-240). Philadelphia: University of Pennsylvania Press.

Leitão, C. \& Nicolaci-da-Costa, A. M. (2000). Psicologia clínica e informática: por que essa inusitada aproximação? Psicologia Clínica, 12(2), 189-205.

Leitão, C. (2003). Impactos subjetivos da Internet: reflexões teóricas e clínicas. Tese de Doutorado. Pontifícia Universidade Católica do Rio de Janeiro, Rio de Janeiro.

Lévy, P. (1993). As tecnologias da inteligência: O futuro do pensamento na era da informática. São Paulo: Editora 34.

Ling, R. (2000). "We will be reached": the use of mobile telephony among Norwegian youth. Information Technology and People, 13(2), 102-120.

Ling, R. (2004). The mobile connection: The cell phone's impact on society. San Francisco: Morgan Kaufmann.

Mäenpäa, P. (2001). Mobile communication as a way of urban life. Em A. Warde \& J. Gronow (Orgs.), Ordinary consumption (pp. 107-123). Londres: Routledge.

Marino, A. A., Nilsen, E. \& Frilot, C. (2003). Nonlinear changes in brain electrical activity due to cell phone radiation. Bioelectromagnetics, 24(5), 339-346.

Nicolaci-da-Costa, A. M. (1989) Questões metodológicas sobre a análise de discurso. Psicologia: Reflexão e Crítica, 4(1/2), 103-108.

Nicolaci-da-Costa, A. M. (1994). A análise de discurso em questão. Psicologia: Teoria e Pesquisa, 10(2), 317-331.

Nicolaci-da-Costa, A. M. (1998). Na malha da rede: Os impactos intimos da internet. Rio de Janeiro: Campus.

Nicolaci-da-Costa, A. M. (2002a). Revoluções tecnológicas e transformações subjetivas. Psicologia: Teoria e Pesquisa, 18(2), 193-202.

Nicolaci-da-Costa, A. M. (2002b). Internet: A negatividade do discurso da mídia versus a positividade da experiência pessoal. À qual dar crédito? Estudos de Psicologia (UFRN), 7(1), 25-35.

Nisbet, R. A. (1966). The sociological tradition. New York: Basic Books.

Plant, S. (2001). On the mobile: The effects of mobile telephones on social and individual life. Retirado em 20/05/2002, do http:// www.motorola.com/mot/documents/0,1028,296,00.pdf

Rheingold, H. (2003). Smart mobs: The next social revolution. Cambridge, Mass.: Perseus Books.

Roberts, S., Crabtree, J. \& Nathan, M. (2003). Mobile UK - mobile phones and everyday life. Retirado em 12/03/2003, do http:// www.theworkfoundation.com/research/isociety/MobileUK_ main.jsp

Romão-Dias, D. (2001). Nossa plural realidade: Um estudo sobre a subjetividade na era da internet. Dissertação de Mestrado, Pontifícia Universidade Católica do Rio de Janeiro, Rio de Janeiro.

Roos, J. P. (2001). Postmodernity and mobile communications. Retirado em 03/07/2004, do http://www.valt.helsinki.fi/staff/ jproos/mobilezation.htm

Sennett, R. (1998). A corrosão do caráter: Conseqüências pessoais do trabalho no novo capitalismo. Rio de Janeiro: Record.

Strayer, D. L. \& Johnston, W. A. (2001). Driven to distraction: Dualtask studies of simulated driving and conversing on a cellular telephone. Psychological Science, 12(6), 462-466.

Turkle, S. (1997). Life on the screen: Identity in the age of the internet. New York: Toutchstone. 
Wilson, J., Fang, M., Wiggins, S. \& Cooper, P. (2003). Collision and violation involvement of drivers who use cellular phones. Traffic Injury Prevention, 4(1), 45-52.
Recebido em 30.09.2003 Primeira decisão editorial em 20.01.2004 Versão final em 11.06.2004 Aceito em 30.06.2004

IV CONPSI

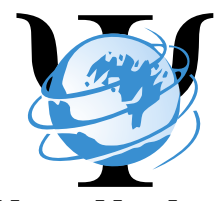

\section{Congresso Norte Nordeste de Psicologia}

Psicologia: Novas Direções com Outros Campos do Saber

Data: 25 a 28 de maio de 2005

Local: Salvador-BA

Entidades Organizadoras:

Departamento de Psicologia da UFBA

CRP-03 Bahia e Sergipe

A recepção dos trabalhos ocorrerá a partir de 08 de novembro de 2004.

Informações:

http://www.conpsi.psc.br conpsi@conpsi.psc.br 